\title{
Chromosome identification in the Andean common bean accession G19833 (Phaseolus vulgaris L., Fabaceae)
}

\author{
Sarah Altrock, Artur Fonsêca and Andrea Pedrosa-Harand \\ Laboratório de Citogenética Vegetal, Departamento de Botânica, Universidade Federal de Pernambuco, \\ Recife, PE, Brazil.
}

\begin{abstract}
Characterization of all chromosomes of the Andean G19833 bean genotype was carried out by fluorescent in situ hybridization. Eleven single-copy genomic sequences, one for each chromosome, two BACs containing subtelomeric and pericentromeric repeats and the $5 S$ and $45 S$ ribosomal DNA ( $\mathrm{rDNA}$ ) were used as probes. Comparison to the Mesoamerican accession BAT93 showed little divergence, except for additional 45S rDNA sites in four chromosome pairs. Altogether, the results indicated a relative karyotypic stability during the evolution of the Andean and Mesoamerican gene pools of $P$. vulgaris.
\end{abstract}

Key words: common bean, repetitive DNA, chromosome marker, cytogenetic map, comparative map, intraspecific variation.

Received: December 3, 2010; Accepted: February 28, 2011.

The common bean (Phaseolus vulgaris L.) is one of the main legume crops worldwide, with special dietary value for Latin America and Africa, where it represents a major source of proteins (Broughton et al., 2003). Despite its economical importance, genomic knowledge is still limited. Although full-genome sequences are available for such crops as rice (Goff et al., 2002) and grapevine (Jaillon et al., 2007), among warm-season legume crops, such as the common bean, only soybean has been sequenced so far (Schmutz et al., 2010).

Due to its distribution in the wild and two major domestication centers, $P$. vulgaris germplasm is comprised of two main gene-pools, the Andean and the Mesoamerican (Singh et al., 1991). The Mesoamerican breeding line BAT93, a parent of the main mapping population BAT93 $\mathrm{x}$ Jalo EEP558 (Freyre et al., 1998), has desirable characteristics, such as broad adaptation and disease resistance (Gepts et al., 2008). A large BAC library exists for this Mesoamerican cultivar (Kami et al., 2006) and clones from this library were used for establishing the cytogenetic map of the common bean integrated to its genetic maps (Pedrosa-Harand et al., 2009; Fonsêca et al., 2010). G19833, a Peruvian landrace, is a parent of the principal mapping population used at CIAT (Centro Internacional de Agricultura Tropical, Cali, Colombia), DOR364 x G19833 (Blair et al., 2003). Furthermore, Ramírez et al. (2005) developed ex-

Send correspondence to Andrea Pedrosa-Harand. Laboratório de Citogenética Vegetal, Departamento de Botânica, Universidade Federal de Pernambuco, R. Prof. Nelson Chaves $s / \mathrm{h}$, Cidade Universitária, 50670-420 Recife, PE, Brazil. E-mail: andrea.pedrosaharand@pesquisador.cnpq.br. pressed sequence tags (ESTs) from cDNA libraries of the Andean G19833 and the Mesoamerican variety 'Negro Jamapa'. Recently, a G19833 BAC library was used for BAC-end sequencing and the development of a draft physical map of P. vulgaris (Schlueter et al., 2008). Currently, G19833 is also being sequenced by a group of US laboratories (S. Jackson, personal communication), thus showing the importance of G19833 for studies on the $P$. vulgaris genome structure, as well as for comparative studies in the Phaseolus genus (Gepts et al., 2008).

Several common bean accessions, including BAT93 and G19833, have been compared cytologically and they have shown large variation in the number and size of $45 \mathrm{~S}$ rDNA loci (Pedrosa-Harand et al., 2006). Other repetitive sequences present in BAC inserts and localized in BAT93 (Pedrosa-Harand et al., 2009; Fonsêca et al., 2010) have not been analyzed in Andean accessions. Three out of four BACs defined for karyotyping in common bean contained repetitive sequences that may also vary in distribution between gene pools, hampering chromosome identification. Herein, the G19833 metaphase chromosomes were identified using single-copy probes previously mapped in BAT93, as a means of comparing chromosome distribution of repetitive sequences, and so contribute to G19833 genomic characterization.

Seeds of the $P$. vulgaris accession G19833 were obtained from the germplasm bank of the Embrapa Arroz e Feijão, Brazil. Root-tip pretreatment, fixation and storage, as well as mitotic chromosome preparation and the FISH procedure, have already been described by Fonsêca et al. (2010). Among the probes previously mapped in BAT93 
(Pedrosa-Harand et al., 2009; Fonsêca et al., 2010), 10 single-copy BAC clones [221F15 (chromosome 1), 127F19 (chr. 2), 174E13 (chr. 3), 36H21 (chr. 5), 18B15 (chr. 6), 22I21 (chr. 7), $177 \mathrm{I} 19$ (chr. 8), 224I16 (chr. 9), 173P6 (chr. 10 ) and 255F18 (chr. 11)], one single-copy bacteriophage [B61 (chr. 4)], repetitive probes, such as a 5S (D2) and a 45S (R2) rDNA plasmid, a pericentromeric (12M3), and a subtelomeric (63H6) BAC, were all chosen for hybridization. All the selected clones were labeled by nick translation (Invitrogen or Roche) with either Cy3-dUTP (GE) or digoxigenin-11-dUTP (Roche). When necessary, either $P$. vulgaris $C_{0} t-1$ or $C_{0} t-100$ fractions, isolated according to Zwick et al. (1997), were added to the hybridization mixtures in 20-, 70- or 100-fold excess of probe concentration $(5 \mathrm{ng} / \mu \mathrm{L})$ to block repetitive sequences. FISH images were captured by an epifluorescence Leica DMLB microscope equipped with a Cohu CCD video camera using Leica QFISH software. Pictures were superimposed and artificially colored using the Adobe Photoshop software version 10.0 and adjusted for brightness and contrast. The BAT93 idiogram (Pedrosa-Harand et al., 2009; Fonsêca et al., 2010) was modified to schematically represent the differences observed in the G19833 chromosome complement. Chromosomes were named and oriented according to standard common bean nomenclature (Pedrosa-Harand et al., 2008).

Each chromosome-specific marker identified one out of the eleven G19833 chromosome pairs (see, for example, BAC 177119 in Figure 1a,c). Unlike BAT93 (Fonsêca et al., 2010), no additional signal was observed in chromo- some 7 after hybridization with BAC 255F18 (Figure 1a,c), thereby confirming the absence of this repetitive block in the Andean accessions of the species (T.R.B. dos Santos, A. Fonsêca, K.G.B. dos Santos and A. Pedrosa-Harand, unpublished results). As for other species with chromosomes that are small and similar in morphology, such as the ones from common bean, BACs were essential for chromosome identification (Dong et al., 2000; Kim et al., 2005; Wang et al., 2008).

When blocking DNA was required in the hybridization mixture for BAT93, the same amount of $C_{0} t-100$ was added to G19833 and comparable results were obtained. Various amounts of $C_{0} t-1$ and $C_{0} t-100$ were tested only for BAC $36 \mathrm{H} 21$. No or insufficient blocking was observed after the use of a 70- and 100-fold excess of $C_{0} t-1$, although unique signals were still obtained when $70 \mathrm{x} C_{0} t-100$ was used, as was the case for BAT93 (data not shown). Due to different reassociation times in the production of $C_{0} t-1$ and $C_{0} t-100$ fractions, $C_{0} t-1$ contains highly repetitive sequences only, whereas $C_{0} t-100$ contains highly and moderately repetitive components of the genome (Zwick et al., 1997). This difference was visualized in tomato after the chromosomal localization of the $C_{0} t-1, C_{0} t-10$ and $C_{0} t-100$ repetitive DNA fractions (Chang et al., 2008). FISH signals of labelled $C_{0} t$ fractions indicated $45 \mathrm{~S}$ rDNA and telomere repeat predominance in $C_{0} t-1$, whereas $C_{0} t-100$ DNA signals were observed along all the chromosomes, except for certain interstitial and distal regions (Chang et al., 2008). The more effective blocking with $C_{0} t-100$ confirmed the presence of moderately repetitive sequences in BAC

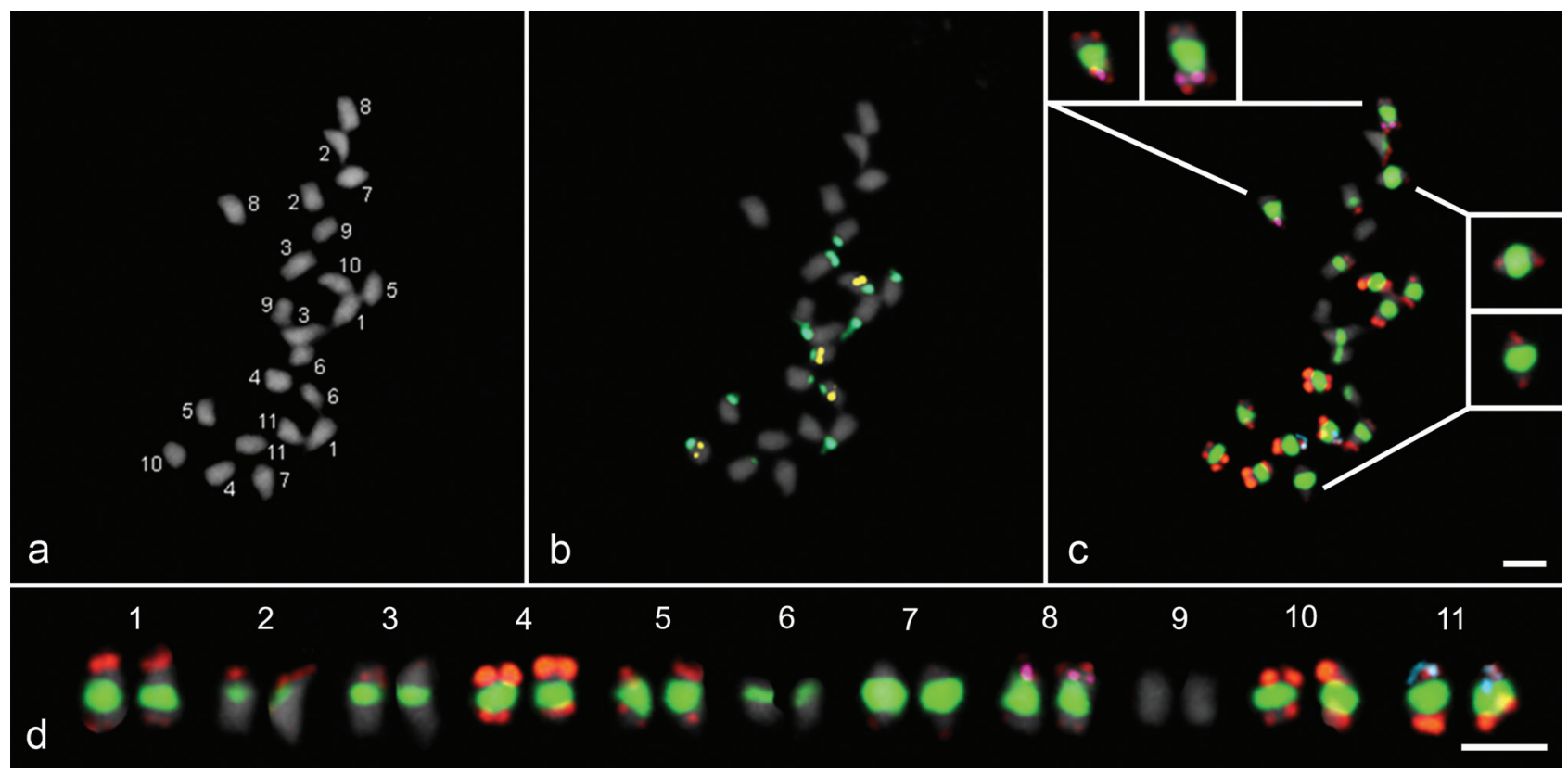

Figure 1 - FISH of repetitive and single-copy sequences in a metaphase of the Andean common bean accession G19833. a) Chromosomes counterstained with DAPI are numbered from 1 to 11, as identified by FISH; b) 5S (yellow) and 45S (dark green) rDNA loci; c) Clones 63H6 (subtelomeric; orange), $12 \mathrm{M} 3$ (pericentromeric; light green), $177 \mathrm{I} 19$ (chromosome 8; pink) and 255F18 (chromosome 11; blue). In inserts, chromosomes in a higher magnification showing hybridization signals of the subtelomeric clone 63H6; d) Karyogram. Bar in (c) and (d) represents $2.5 \mu \mathrm{m}$. 
$36 \mathrm{H} 21$. This blocking strategy is recommended for FISH experiments with BACs showing similar distribution patterns.

The sequential use of single-copy and repetitive BAC clones enabled the characterization of the G19833 karyotype, based on the distribution of subtelomeric and pericentromeric sequences in each chromosome pair. The hybridization patterns observed with the BACs $63 \mathrm{H} 6$ and $12 \mathrm{M} 3$ were similar to those described for BAT93 (Fonsêca et al., 2010). In chromosomes 1, 4, 5, 7, 8, 10 and 11, signals from BAC $63 \mathrm{H} 6$ were apparent on both arms, with the strongest signals on chromosome 4 . Chromosome 2 and 3 showed signals on the short arms only, the same occurring on the long arm of chromosome 6. Only chromosome $9 \mathrm{did}$ not show any signal (Figure. 2). BAC 12M3 signals were detected in all the chromosomes, the weakest in chromosome 9 (Figure 2). As all the 11 chromosome pairs were identified with the same subset of only four BACs (Figure 1a,c), a karyogram showing all of them could be built (Figure 1d). The most pronounced difference from BAT93 was observed for chromosome 10, in that the signals from BAC $63 \mathrm{H} 6$ appeared to be more terminal on the long arm in the Andean cultivar. This results from the difference in size of the $45 \mathrm{~S}$ rDNA site present at the end of this arm in both accessions.

It was confirmed that the major karyotypic difference between these Andean and Mesoamerican gene pool accessions is related to the distribution of the $45 \mathrm{~S}$ ribosomal DNA sites. In a previous analysis of 37 samples, between six and nine loci were detected in Andean accessions, whereas in Mesoamerican there were only three, rarely four 45S rDNA loci (Pedrosa-Harand et al., 2006). The number of $5 \mathrm{~S}$ rDNA loci was conserved, with two loci per haploid genome (Figure 1b). In BAT93, only chromosomes 6, 9 and 10 bore 45S rDNA loci (Fonsêca et al., 2010), whereas in G19833, signals had previously been detected in seven chromosome pairs (Pedrosa-Harand et al., 2006). Through the identification of all the chromosomes in the present work, it was possible to recognize those bearing $45 \mathrm{~S}$ rDNA, and thus characterize the respective chromosome-specific signal patterns. Chromosomes 1, 3, 4, 5, 6, 9 and 10 carry $45 \mathrm{~S}$ sequences more terminally than the subtelomeric sequences hybridized with BAC 63H6 (Figure 1b). The strongest signals were detected in chromosomes 1 and 3, with a gradual decrease in intensity in 5 and 10 , followed by chromosomes 6 and 9 , the weakest signal being detected in chromosome 4 . Whereas, in chromosome pairs 4, 5 and 10, 45S rDNA loci were on the long arm, in 1, 3, 6 and 9, these were on the short arm. Contrary to BAT93, the 45S rDNA signal detected in chromosome 10 of G19833 seems to be weaker than that in chromosome 6 (Figure 1b). By using the idiogram developed for BAT93 (Fonsêca et al., 2010), a schematic representation of G19833 chromosomes, showing the approximate distribution of repetitive sequences and chromosome markers, was established (Figure 3).

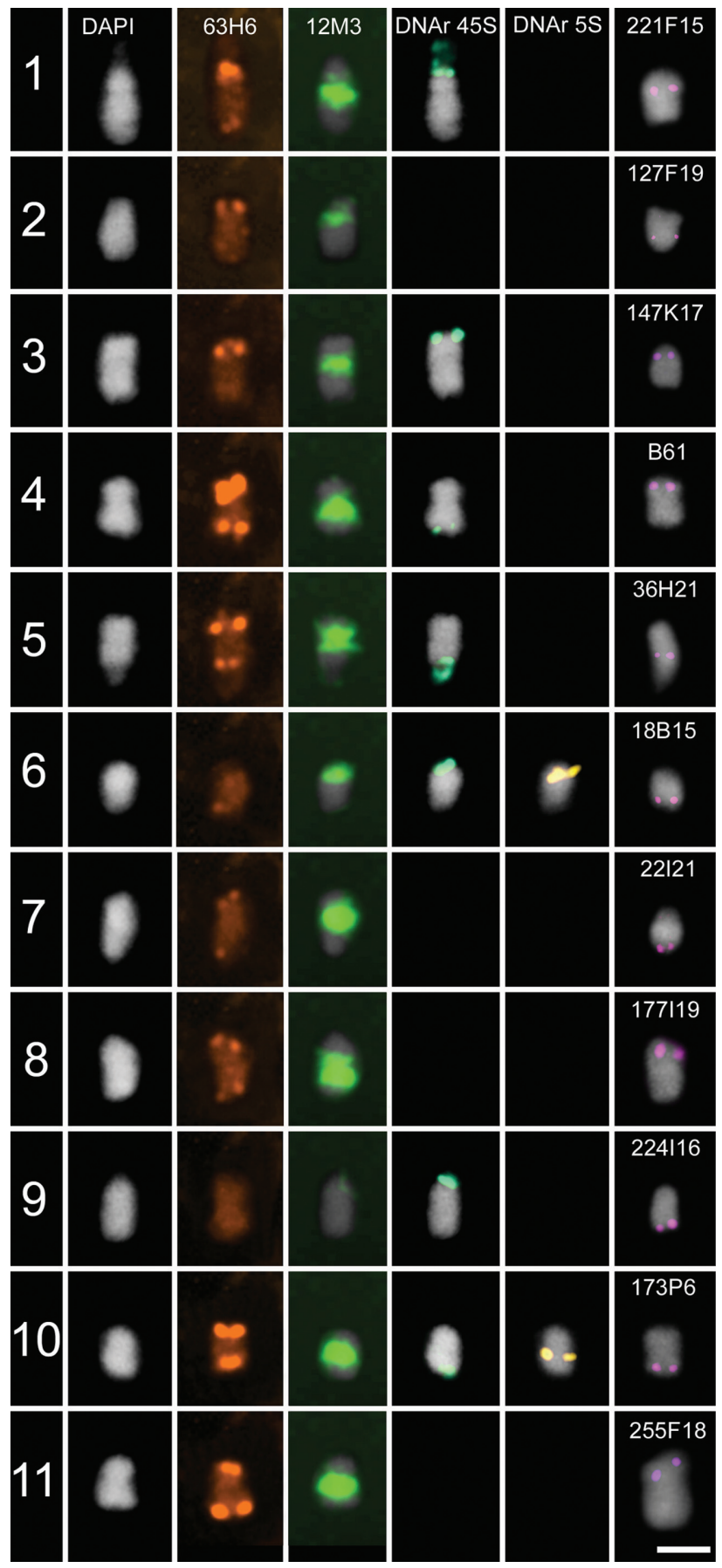

Figure 2 - Distribution of repetitive sequences and localization of single-copy sequences on G19833 metaphase chromosomes counterstained with DAPI: subtelomeric (BAC 63H6; orange) and pericentromeric (BAC 12M3; light green) sequences; 45S (dark green) and 5S (yellow) rDNAs, as well as single-copy genomic clones (BACs and one bacteriophage; violet). Except for single-copy genomic clones, the chromosomes were obtained from one and the same metaphase, thus allowing for comparison of the intensity of hybridization signals. Scale bar represents $2.5 \mu \mathrm{m}$.

Altogether, a comparison between the present results for G19833 and previous ones for BAT93 (Fonsêca et al., 2010) revealed only a slight karyotypic divergence between these accessions, mainly restricted to the $45 \mathrm{~S}$ rDNA loci, 

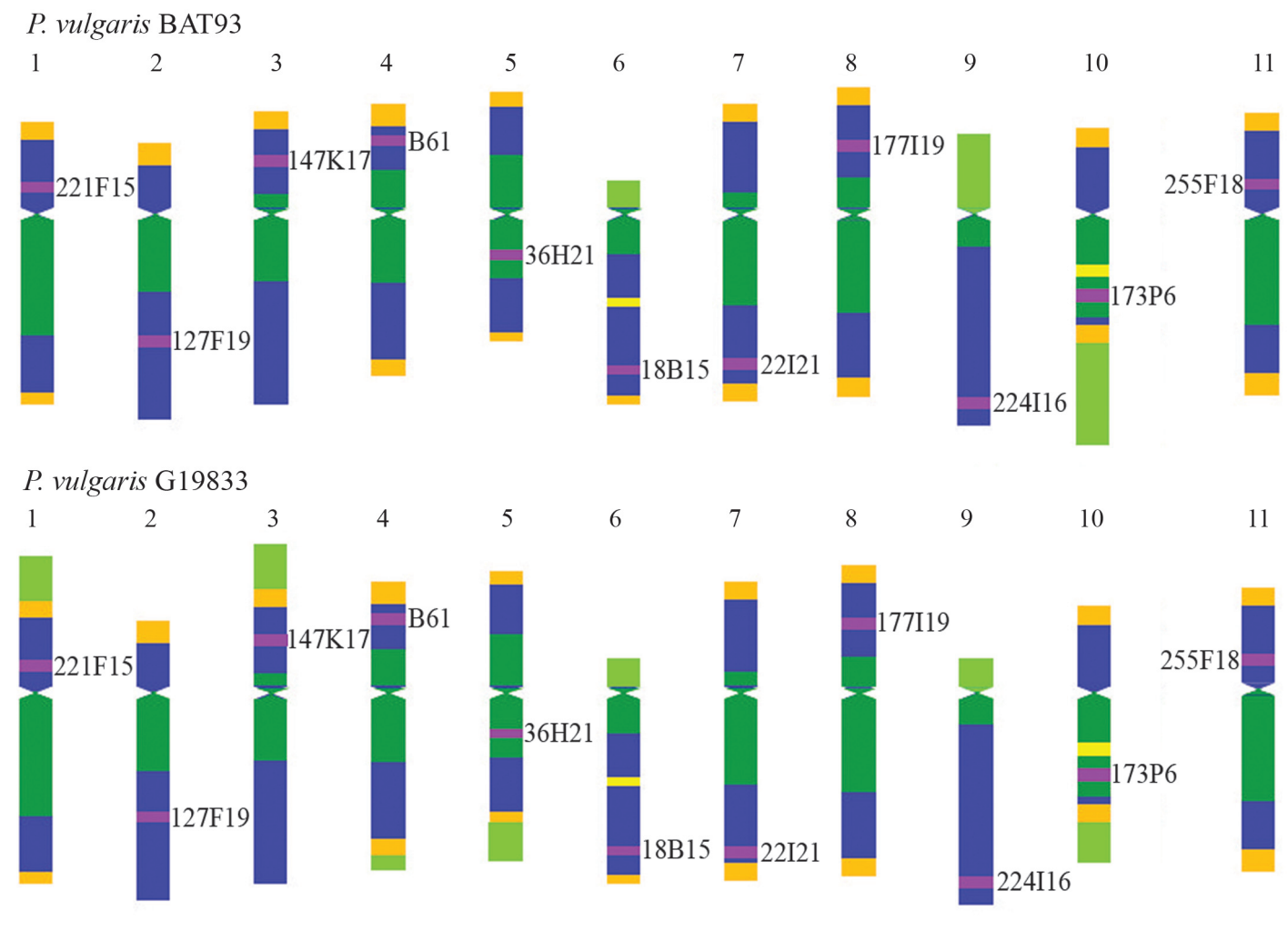

$\square$ Single-copy BACs $\square$ Pericentromeric BACs

$\square$ Subtelomeric BACs

๑ 5 $\mathrm{SDNA}$

10

11

Figure 3 - Modified idiogram of BAT93 (Pedrosa-Harand et al, 2009; Fonsêca et al., 2010) and schematic representation of G19833 chromosomes, showing the distribution patterns of repetitive sequences. Approximate positions of chromosome markers are also indicated.

thereby implying relative stability in the distribution of pericentromeric and subtelomeric repeats among the Andean and Mesoamerican lineages during evolution. Therefore, despite the variation observed for BAC 255F18, the chromosomes of G19833 could be differentiated using the same set of BACs previously used for chromosome identification in BAT93. The combination of nine tandemly repeated DNA sequences as probes also facilitated identification of all the maize chromosome pairs in 14 lines, although more pronounced differences in the distribution of knob, microsatellite, centromeric and subtelomeric sequences were observed among these maize accessions (Kato et al., 2004) than between the common bean accessions analyzed here. The identification of all the G19833 chromosomes could be useful in further analyses of the genomic structure of this Andean common bean.

\section{Acknowledgments}

We wish to thank James Kami and Paul Gepts (University of California) for providing the BAC clones, Valérie Geffroy for providing the bacteriophage, EMBRAPA Arroz e Feijão for supplying the seeds, and the Conselho Nacional de Desenvolvimento Científico e Tecnológico (CNPq), Brazil, for financial support.

\section{References}

Blair MW, Pedraza F, Buendia HF, Gaitán-Solís E, Beebe SE, Gepts P and Tohme J (2003) Development of a genomewide anchored microsatellite map for common bean (Phaseolus vulgaris L.). Theor Appl Genet 107:1362-1374.

Broughton WJ, Hernandez G, Blair M, Beebe S, Gepts P and Vanderleyden J (2003) Beans (Phaseolus spp.) - Model food legumes. Plant Soil 252:55-128.

Chang S-B, Yang T-J, Datema E, van Vugt J, Vosman B, Kuipers A, Meznikova M, Szinay D, Klein Lankhorst R, Jacobsen E, et al. (2008) FISH mapping and molecular organization of the major repetitive sequences of tomato. Chromosome Res 16:919-933.

Dong F, Song J, Naess SK, Helgeson JP, Gebhardt C and Jiang J (2000) Development and applications of a set of chromosome-specific cytogenetic DNA markers in potato. Theor Appl Genet 101:1001-1007.

Fonsêca A, Ferreira J, dos Santos TRB, Mosiolek M, Bellucci E, Kami J, Gepts P, Geffroy V, Schweizer D, dos Santos KGB, et al. (2010) Cytogenetic map of common bean (Phaseolus vulgaris L.). Chromosome Res 18:487-502.

Freyre R, Skroch PW, Geffroy V, Adam-Blondon AF, Shirmohamadali A, Johnson WC, Llaca V, Nodari RO, Pereira PA, Tsai SM, et al. (1998) Towards an integrated linkage map of common bean: 4 . Development of a core linkage map and alignment of RFLP maps. Theor Appl Genet 97:847-856. 
Gepts P, Aragão FJL, de Barros E, Blair MW, Brondani R, Broughton W, Galasso I, Hernández G, Kami J, Lariguet P, et al. (2008) Genomics of Phaseolus beans, a major source of dietary protein and micronutrients in the tropics. In: Moore PH and Ming R (eds) Genomics of Tropical Crop Plants. Springer, Berlin, pp 113-143.

Goff SA, Ricke D, Lan T-H, Presting G, Wang R, Dunn M, Glazebrook J, Sessions A, Oeller P, Varma H, et al. (2002) A draft sequence of the rice genome (Oryza sativa L. spp.japonica). Science 296:92-100.

Jaillon O, Aury JM, Noel B, Policriti A, Clepet C, Casagrande A, Choisne N, Aubourg S, Vitulo N, Jubin C, et al. (2007) The grapevine genome sequence suggests ancestral hexaploidization in major angiosperm phyla. Nature 449:463-467.

Kami J, Poncet V, Geffroy V and Gepts P (2006) Development of four phylogenetically-arrayed BAC libraries and sequence of the APA locus in Phaseolus vulgaris. Theor Appl Genet 112:987-998.

Kato A, Lamb JC and Birchler JA (2004) Chromosome painting using repetitive DNA sequences as probes for somatic chromosome identification in maize. Proc Natl Acad Sci USA 101:13554-13559.

Kim J-S, Klein PE, Klein RR, Price HJ, Mullet JE and Stelly DM (2005) Chromosome identification and nomenclature of Sorghum bicolor. Genetics 169:1169-1173.

Pedrosa-Harand A, de Almeida CCS, Mosiolek M, Blair MW, Schweizer D and Guerra M (2006) Extensive ribosomal DNA amplification during Andean common bean (Phaseolus vulgaris L.) evolution. Theor Appl Genet 112:924-933.

Pedrosa-Harand A, Porch T and Gepts P (2008) Standard nomenclature for common bean chromosomes and linkage groups. Annu Rep Bean Improv Coop 51:106-107.
Pedrosa-Harand A, Kami J, Gepts P, Geffroy V and Schweizer D (2009) Cytogenetic mapping of common bean chromosomes reveals a less compartmentalized small-genome plant species. Chromosome Res 17:405-417.

Ramírez M, Graham MA, Blanco-López L, Silvente S, Medrano-Soto A, Blair MW, Hernández G, Vance CP and Lara M (2005) Sequencing and analysis of common bean ESTs. Building a foundation for functional genomics. Plant Physiol 137:1211-1227.

Schlueter JA, Goicoechea JL, Collura K, Gill N, Lin JY, Yu Y, Kudma D, Zuccolo A, Vallejos CE, Muñoz-Torres M, et al. (2008) BAC-end sequence analysis and a draft physical map of the common bean (Phaseolus vulgaris L.) genome. Trop Plant Biol 1:40-48.

Schmutz J, Cannon SB, Schlueter J, Ma J, Mitros T, Nelson W, Hyten DL, Song Q, Thelen JJ, Cheng J, et al. (2010) Genome sequence of the palaeopolyploid soybean. Nature 463:178-183.

Singh SP, Gepts P and Debouck DG (1991) Races of common bean (Phaseolus vulgaris L., Fabaceae). Econ Bot 45:379396.

Wang K, Guan B, Guo W, Zhou B, Hu Y, Zhu Y and Zhang T (2008) Completely distinguishing individual A-genome chromosomes and their karyotyping analysis by multiple bacterial articial chromosome-fluorescence in situ hybridization. Genetics 178:1117-1122.

Zwick MS, Hanson RE, McKnight TD, Islam-Faridi MH, Stelly DM, Wing RA and Price HJ (1997) A rapid procedure for isolation of $C_{0} t-1$ DNA from plants. Genome 40:138-142.

Associate Editor: Angela M. Vianna-Morgante

License information: This is an open-access article distributed under the terms of the Creative Commons Attribution License, which permits unrestricted use, distribution, and reproduction in any medium, provided the original work is properly cited. 